\title{
El perro que dijo ¡miau!
}

\section{Matias Ortiz}

Doña Lorena era una señora a la que le encantaban los gatos. Ella los rescataba de la calle y les daba un lugar para comer y vivir en su hogar.

Doña Lorena era ciega, pero era una señora muy hábil. Todos los gatos la amaban y la ayudaban con los quehaceres de la casa. Tenía cuatro gatos: Felix, Aldo, Fito y Lora.

Un día mientras Doña Lorena estaba caminando hacia la tienda, escuchó a un gato decir "miau" débilmente. Se paró y empezó a llamar al gato "ven aquí gatito" hasta que sintió que el animal se le acercaba. Cuando el gato finalmente se acercó, Doña Lorena se confundió un poco porque su pelaje no era como el pelo de un gato. Pero como Doña Lorena aceptaba a todos los gatos, entonces sin pesar levantó al gato y se lo trajo a su casa.

Cuando el gato llegó a la casa de Doña Lorena, los otros gatos se pusieron furiosos. Es que el gato que Doña Lorena había traído a la casa, en realidad, era un shih tzu llamado Max.

Max era un perro muy consciente de sí mismo. No estaba a gusto con su apariencia, entonces vivía su vida imitando a los gatos.

“¿Qué piensas que haces?”-reclamó Felix.

"¿De qué hablas?"—contestó Max.

“¡Esta es una casa para gatos!”- dijo Aldo.

"¡Pero si yo soy un gato!"-insistió Max.

Pasaron un par de días y algunos de los gatos empezaron a ignorarlo a Max. Cuando era la hora del almuerzo, todos los gatos corrían a sus platos para terminar su comida antes que Max tuviera una oportunidad de comer.

Max sólo quería ser como ellos, pero sentía que nadie lo entendía, y que lo juzgaban por ser un perro.

Fito y Lora vieron que nadie le hablaba a Max. Un día, mientras Max jugaba solo con una pelota, se acercaron hacia él.

“¿Qué haces?”- - preguntó Fito.

"Solo quiero que alguien juege conmigo, pero todos me tratan como si fuera diferente"—reclamó Max.

Lora se acercó y le pasó la pelota. Pasaron toda la tarde hablando de los problemas de los animales de la casa. Fito y Lora se dieron cuenta que tenían más en común con él de lo que pensaban. Desde ese día, Lora, 
Fito, y Max fueron inseparables. Ellos le daban ánimo cuando los otros gatos lo trataban mal. Lo defendían diciéndole a los otros gatos que nadie había tomado el tiempo para conocerlo y que lo juzgaban solo por se diferente.

Una noche mientras todos dormían, Max escuchó un ruido que vino desde la cocina. Max intentó despertar a los gatos pero nadie se molestó. Cuando vio que nadie le prestaba atención, Max decidió ir a la cocina para ver de dónde venía todo el ruido.

¡Max encontró una familia de mapaches robando toda la comida de Doña Lorena! Él no supo qué hacer pero sabía que tenía que advertirle a los otros. Uno de los mapaches vio a Max y reclamó "itenemos que apurarnos, tienen un perro!" Max inmediatamente empezó a decir "imiau!" lo más fuerte que pudo. Cuando los mapaches escucharon esto empezaron a reír incontrolablemente.

"¡Es un perro que no sabe cómo ladrar!”-decían ellos.

Max se empezó a enojar y siguió diciendo "¡miau!" cada vez más fuerte, esperando que uno de los gatos se despertara, pero nadie vino. En un momento de enojo y frustración, Max ladró por la primera vez en años. Su ladrido fue tan fuerte que los mapaches se congelaron.

Doña Lorena se despertó inmediatamente y corrió hacia la cocina donde escuchó a la familia de mapaches robando toda la comida que ella había preparado.

Max se dio cuenta de que sus diferencias eran lo que lo hacían único. Gracias a su ladrido Doña Lorena encontró a la familia de mapaches y los gatos nunca volvieron a burlarse de Max. Algunas veces en la vida tenemos que ladrar en una casa llena de gatos. 